\title{
Alfabetização de Jovens e Adultos: um Estudo Etnográfico
}

Pesquisadora: Ruth da Cunha Pereira Instituição:

Universidade Estácio de Sá (Unesa) Fonte

Financiadora: Unesa

O analfabetismo é um fenô- tando a negação do direito fundameno social profundamente insta- mental do cidadão de aprender, lado em diversos países, represen- conhecer e comunicar-se. Atual- 
mente, pode-se verificar no mundo cerca de um bilhão de adultos que não sabem 1er nem escrever um simples texto sobre a vida cotidiana (Unesco, 1994). Esse número pode ainda ser maior, ao se considerar também a questão do analfabetismo funcional que atinge a muitas pessoas que, ao deixarem de freqüentar a escola, perderam o hábito de 1 er e escrever. Acresce que cerca de 130 milhões de crianças em idade escolar não têm acesso aos estabelecimentos de ensino, estão fora da escola (Unesco, 1994), ameaçando aumentar cada vez mais o contingente de adultos analfabetos no século XXI. De fato, criar no mundo condições para que todos os homens possam alfabetizar-se representa um grande desafio que precisa ser enfrentado.

Esta realidade apontada pela Unesco é, igualmente, constatada no Brasil. Apesar de diversas iniciativas proclamadas pelo governo no sentido da alfabetização de todos os brasileiros, através dos tempos, pode-se dizer que não se conseguiu, até hoje, erradicar o problema do analfabetismo existente em nosso País.
Assim, verifica-se que, no III Plano Setorial de Educação, Cultura e Desporto: 1980-1985 (Brasil, 1980), a educação é vista dentro da ótica da política social, havendo o compromisso de colaborar com a redução das desigualdades sociais e voltando-se preferencialmente para a população de baixa renda. Ele aponta como prioridade a educação básica, onde a alfabetização tem um papel preponderante. Da mesma forma o Plano Decenal de Educação para Todos: 1993-2003 (Brasil, 1993) propõe o objetivo mais amplo de "assegurar, até o ano 2003, a crianças, jovens e adultos, conteúdos mínimos de aprendizagem que atendam a necessidades elementares da vida contemporânea" (p. 12-13). Este plano, inclusive, tem sido apresentado como um instrumento de luta para a recuperação da educação básica neste País, exigindo um esforço conjunto de todos os agentes do processo educativo: a União, os Estados, os municípios, as escolas, os professores, os dirigentes escolares, os sindicatos, enfim, toda a sociedade civil. Entretanto, são poucos os movimentos efetivos 
para a concretização deste plano, ainda que seja inegável a importância de ações do MEC, como o Pró-Leitura e o Pró-Ler.

Os percalços são muitos e variados, pois um grande número de adultos, tendo que trabalhar para sua sobrevivência, não dispõe de tempo hábil e condições favoráveis para estudar na busca de realização de seu projeto de vida. Por outro lado, algumas vezes, pela própria exigência do trabalho, se vêem forçados a buscar, de alguma forma, alfabetizar-se.

A alfabetização é fundamental para o ser humano. A deficiência nesta área afeta cada homem e cada mulher como indivíduo e como membro de uma comunidade, constituindo-se num entrave ao desenvolvimento pessoal e social, além de representar uma violação de seu direito fundamental à educação.

Diante da importância desse processo contínuo de alfabetização de jovens e adultos, a Universidade Estácio de Sá (Unesa) procura trazer sua contribuição, ao propor o desenvolvimento de um curso de extensão para atender a essa clientela da comunidade:
"Alfabetização para a prática da cidadania", que teve início em agosto de 1993, como proposta de grande relevância para o trabalho de integração entre universidade e comunidade. Esse curso conta com a participação sistemática de, pelo menos, três professores (uma coordenadora-geral, uma coordenadora adjunta e uma supervisora pedagógica) e três monitoras (estudantes da universidade que voluntariamente aceitaram participar do projeto e que, após a devida seleção, se engajaram em suas atividades, recebendo, para isto, um apoio financeiro da instituição).

Essa nova experiência na Universidade Estácio de Sá fez emergir o projeto de pesquisa com o título "Alfabetização de jovens e adultos: um estudo etnográfico", a partir de inúmeras questões que surgiram na procura de alternativas que atendessem às necessidades desses alunos, tais como: 1) que relação existe entre as habilidades de leitura e escrita identificadas nos alunos que freqüentam o curso de alfabetização e o nível de escolaridade declarada por estes alunos? 2) qual a expectativa desses alunos em relação ao curso em termos de 
sua aprendizagem? 3) que aspectos podem ser identificados nas atividades dos alunos que se mostram como indicadores de seu desenvolvimento no processo de alfabetização para a cidadania? 4) como as monitoras percebem o trabalho que realizam nas turmas formadas para alfabetização de jovens e adultos? e 5) como a equipe coordenadora do curso e as monitoras percebem os fatores que influem no processo de alfabetização de jovens e adultos, no sentido de lhes permitir a utilização da leitura e da escrita para a solução de problemas da vida prática?

Assim sendo, o objetivo da pesquisa, em andamento na Unesa, é analisar os fatores facilitadores ou não do processo de alfabetização de jovens e adultos num curso de extensão. A razão pela qual se optou por este propósito na investigação está muito mais ligada à possibilidade de discutir as relações entre pensamento, linguagem e alfabetização, e de apontar caminhos que favoreçam uma proposta de alfabetização de jovens e adultos, do que à apresentação de diretrizes metodológicas para formação do leitor-escritor.
Dentro de uma abordagem qualitativa da pesquisa educacional (Ezpeletta e Rockwell, 1984, 1986), procura-se integrar a informação histórica local (documental e oral) com a análise etnográfica. A coleta de dados foi feita através da observação participante, discussão da prática das monitoras em reuniões de orientação pedagógica, entrevista, análise de documentos e aplicação de testes para avaliar o nível de linguagem dos alunos. Nesses textos, foram aplicadas aos alunos as provas constitutivas da Escala Alfa (Feldman e Torres, 1992), no que se refere à Identificação de Absurdos e à Narração à vista de Gravura, bem como as da Escala Beta (Feldman et al., 1992), relativas à Categorização de Palavras e à Fluencia Verbal. Foram utilizadas, também, provas constitutivas do Exame de Linguagem Tipiti (Braz e Pellicciotti, 1988), relativas ao Completamento de Sentenças e Compreensão de História Contada pela Pesquisadora).

A pesquisa encontra-se na fase de análise e interpretação dos dados coletados, levando em conta estudos já realizados sobre a história da alfabetização e sobre a história do pensamento do homem. 
Um dos mais consagrados investigadores da historia da alfabetização, Harvey J. GrafF (mencionado por Viñao, 1990), aponta no sentido de uma nova etapa no processo histórico da alfabetização, referente à análise sociohistórica das transformações da mente humana. Nas últimas décadas, os pesquisadores têm convergido sua busca para múltiplos aspectos ligados à literatura e à cultura, numa comunhão de interesses com lingüistas e antropólogos, abrindo um campo promissor para novos estudos sobre a alfabetização, voltados para os processos da comunicação, da linguagem e do pensamento, isto é, da mente humana (Viñao, 1990). Tem-se mostrado importante, portanto, levar em consideração, na evolução desses processos, a questão da linguagem oral, "tê-la ou não tê-la" (p. 126), bem como o tipo de linguagem, com a passagem "da fala para as formas gráficas" (p. 126).

No presente estudo sobre alfabetização de jovens e adultos, toma-se por embasamento teórico a contribuição de Vygotsky (1993), que enfatiza a importância da inte- ração no processo de aprendizagem, uma vez que os processos interativos acontecem primordialmente através da fala, ou seja, através de signos lingüísticos, sendo que na ausência destes só se teria o que o autor chama de um "tipo de comunicação mais primitiva e limitada" (p.5), que seria "a comunicação por meio de movimentos expressivos". É, pois, através da linguagem, que o homem vai constituir-se enquanto sujeito, socialmente engajado na comunidade em que vive. Só assim é possível repensar uma ação pedagógica que possa provocar avanços dos alunos, no sentido do seu acesso à cultura letrada e ao conhecimento construído e acumulado pela ciência.

\section{Referências bibliográficas}

BRASIL. MEC. Secretaria Geral. Plano Setorial de Educação, Cultura e Desporto: 19801985. Brasília, 1980.

BRASIL, Ministério da Educação e do Desporto. Plano Decenal de Educação para Todos. Brasília, 1993. 
BRAZ, HA, PELLICCIOTTI, FELDMAN, J. et al. Escala beta. T.F. Exame de linguagem tipi ti. Buenos Aires: Marymar, 1992. São Paulo: MNJ, 1988.

EZPELETTA, J., ROCKWELL, E. Notas sobre investigación participante y construcción teórica. Brasília: INEP, 1984.

FELDMAN, J., TORRES, MG. Escala alfa. Buenos Aires: Marymar, 1992.

VIÑAO, A. História da alfabetização versus história do pensamento, ou seja, da mente humana. Teoria e Prática, n.2, p. 124-135, 1990.

VYGOTSKY, L.S. Pensamento e linguagem. São Paulo: Martins Fontes, 1993. 